\title{
Effects of heat treatment on the catalytic activity and methanol tolerance of carbon supported platinum alloys
}

\author{
Andiswa Nosipiwo Valisi, T. Maiyalagan*, Lindiwe Khotseng, Vladimir \\ Linkov, Sivakumar Pasupathi* \\ South African Institute for Advanced Materials Chemistry (SAIAMC), University of the Western Cape, \\ Modderdam Road, Bellville 7535, Cape Town, South Africa
}

\begin{abstract}
This work studies the effect of heat treatment of carbon-dispersed platinum and platinum alloys on its methanol tolerance and catalytic activity as gas diffusion electrodes for oxygen reduction reaction (ORR) in acid medium. The catalyst powders were subjected to heat treatments at three different temperatures for a fixed period at controlled atmospheres. Differences in catalyst morphology were characterized using X-ray diffraction, energy dispersive X-ray analysis and transmission electron microscope techniques. The electrochemical characteristics and activity of the electro-catalysts were evaluated for ORR and methanol tolerance using cyclic voltammetry, in the form of gas diffusion electrodes. The optimum heat-treatment temperature is found to be strongly dependent on the individual catalyst. The maximum ORR activity and better methanol tolerance for the oxygen reduction reaction (ORR) was observed in $\mathrm{Pt}-\mathrm{Fe} / \mathrm{C}$ and $\mathrm{Pt}-\mathrm{Cu} / \mathrm{C}$ catalysts subjected to heat treatment at $350^{\circ} \mathrm{C}$.A trend of catalytic activity for oxygen reduction reaction (ORR) was obtained: Pt-Cu/C $\left(350^{\circ} \mathrm{C}\right)>\mathrm{Pt}-\mathrm{Fe} / \mathrm{C}\left(350^{\circ} \mathrm{C}\right)>\mathrm{Pt}-\mathrm{Ni} / \mathrm{C}\left(350^{\circ} \mathrm{C}\right)>\mathrm{Pt}-\mathrm{Co} / \mathrm{C}\left(250^{\circ} \mathrm{C}\right)>$ $\mathrm{Pt} / \mathrm{C}\left(350^{\circ} \mathrm{C}\right)$, showing that $\mathrm{Pt}-\mathrm{Cu} / \mathrm{C}$-type catalysts had a higher catalytic activity with reasonable methanol tolerance.
\end{abstract}

Keywords Electro-catalysts, Heat treatment, oxygen reduction reaction (ORR), Direct methanol fuel cells, sintering.

\section{Introduction}

Direct methanol fuel cells (DMFCs) have received much attention due to a variety of advantages, particularly for portable electrical applications, such as high energy density, low operating temperature and simple processing ${ }^{1,2}$. Despite considerable efforts over the years, there still remains some fundamental problems that needs to be solved, particularly the low activity of oxygen reduction reaction (ORR) electrocatalysts leading to a large overpotential. The best known catalyst for ORR known to-date is platinum, and huge efforts have been made to improve its utilization and activity. However, there are several drawbacks to Pt based catalysts, such as high cost, sensitivity to contaminants, and its low tolerance to methanol as a cathode. In the presence of methanol, platinum displays a formation of mixed potentials, leading to lower current densities and a decrease in the overall efficiency of the 
cell 3-5. In this context, alloying platinum with transition metals is a primary approach and this strategy not only improves the ORR and methanol tolerance, but also decreases the $\operatorname{cost}^{6-10}$. There has been significant efforts in this direction to improve the ORR through binary and ternary platinum catalysts ${ }^{6-14}$, however, there is no clear indication regarding the best binary combination. The literature points towards various $\mathrm{Pt}-\mathrm{M} / \mathrm{C}$ catalysts $(\mathrm{M}=\mathrm{Ni}$, $\mathrm{Co}, \mathrm{Cu}, \mathrm{Sn}$, etc) to have better catalytic activity than $\mathrm{Pt} / \mathrm{C}$ and over other binary catalysts. Many investigations have shown that platinum-based binary metal catalysts, namely Pt$\mathrm{Fe} / \mathrm{C}^{11}, \mathrm{Pt}-\mathrm{Ni} / \mathrm{C}{ }^{12}$, Pt-Co/C ${ }^{13}$, and $\mathrm{Pt}-\mathrm{Cu} / \mathrm{C}^{21}$ exhibits better electro-catalytic activities towards ORR as compared to Pt alone. The discrepancy regarding the best ORR catalyst is mainly due to different methods and conditions used for the preparation these catalysts.

The heat-treatment effect on the Pt catalysts has been well documented ${ }^{15}$; however, a full understanding of catalytic activity improvement for all the Pt and Pt alloys has not yet been achieved. The relationship between heat treatment temperature of various binary catalysts prepared using the same method, towards their performance and methanol tolerance has not been studied/reported yet. It has to be noted that most of these binary catalysts have shown better methanol oxidation activity as compared to platinum alone. During ORR in methanol-containing solutions, the MOR can compete with ORR, therefore the best binary catalysts in pure oxygen medium might not be the best in methanol containing oxygen medium. In brief, the best Pt alloy catalyst with higher methanol tolerance and higher activity for the oxygen reduction reaction than Pt is still unclear.

In this paper, we aim to identify the most ORR active and methanol tolerant Pt based binary catalyst by using catalysts supplied by a well established entity and systematically study the heat-treatment effect on their morphology, activity and methanol tolerance. Well known and widely studied carbon supported platinum $(\mathrm{Pt} / \mathrm{C})$ and $\mathrm{Pt}$ based binary catalysts (Pt$\mathrm{Co} / \mathrm{C}, \mathrm{Pt}-\mathrm{Cu} / \mathrm{C}, \mathrm{Pt}-\mathrm{Fe} / \mathrm{C}$ and $\mathrm{Pt}-\mathrm{Ni} / \mathrm{C}$ ), reported to have exhibited better catalytic activities than $\mathrm{Pt}$ alone, were subjected to controlled systematic heat-treatment procedures and studied thoroughly for their ORR and methanol-tolerant ability in acid medium. 

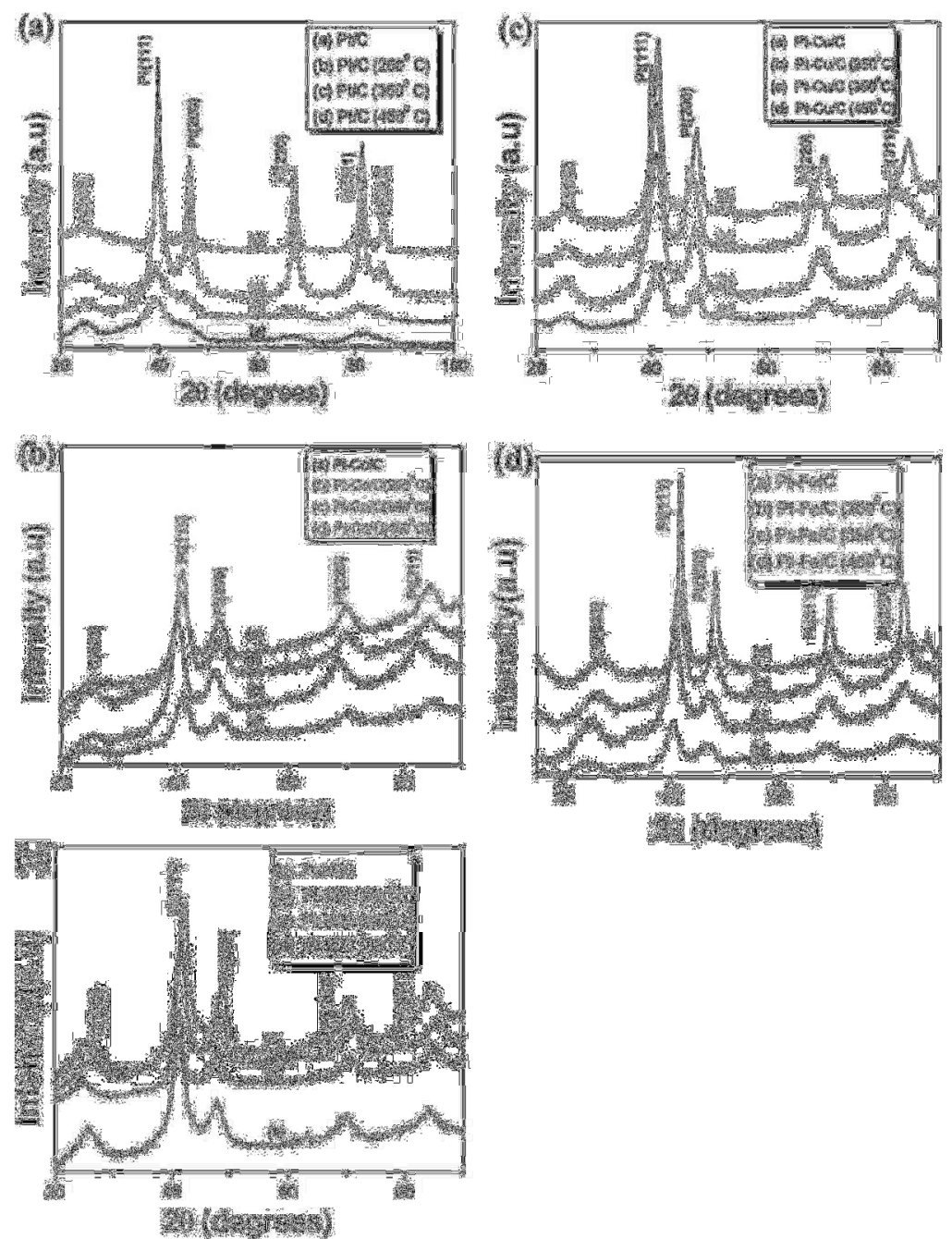

Figure 1.XRD pattern of (a) Pt/C (b) Pt-Co/C (c) Pt-Cu/C (d) Pt-Fe/C and (e) $\mathrm{Pt}-\mathrm{Ni} / \mathrm{C}$ catalyst

Electrochemical and physical characterizations such as cyclic voltammetry, TEM, EDS and XRD analysis were carried out to study and identify the best cathode catalyst for DMFCs.

\section{Experimental}

\subsection{Chemicals and Materials Used}

Nafion 117 (5 w/v in 2-propanol) manufactured by DuPont (Wilmington, DE) was purchased from Sigma-Aldrich Chemical Co. Commercially available catalysts with 20 wt. \% Pt/C, 20 wt. \% Pt-Co/C, 20\% Pt-Cu/C, 20\% Pt-Fe/C, and 20\% Pt-Ni/C alloy catalyst 1:1 atomic composition, purchased from BASF (Tokyo, Japan). Carbon paper was provided by Elchemie Inc. Ultra-pure water from Zeener Power Water Purification System. Methanol, Isopropanol and Ethanol were purchased from Alfa Aesar.

\subsection{Heat Treatment of catalysts}

The following catalysts were treated at different temperatures under controlled atmospheres, to increase the sintering, to remove any undesirable impurities resulting from early preparation stages, to allow a uniform dispersion and stable distribution of the metal on the support, and therefore to improve the electro-catalytic activity of the catalysts. An 
alumina boat loaded with a certain amount of $20 \% \mathrm{Pt} / \mathrm{C}, \mathrm{Pt}-\mathrm{Co} / \mathrm{C}, \mathrm{Pt}-\mathrm{Cu} / \mathrm{C}, \mathrm{Pt}-\mathrm{Fe} / \mathrm{C}$ and Pt$\mathrm{Ni} / \mathrm{C}$ was inserted into the center of a quartz tube. The tube was pre-purged with dry nitrogen gas flowing at $500 \mathrm{ml} / \mathrm{min}$ for $45 \mathrm{~min}$ to suppress possible surface oxidation of $\mathrm{Pt}$ particles due to the remaining oxygen within the tube during the heat treatment. Then the quartz tube was inserted into the tube furnace which was pre-heated to a target temperature. The samples were heated at several target temperatures from 250 to $450^{\circ} \mathrm{C}$ for 3 hours under nitrogen flowing simultaneously at a rate of $5 \mathrm{ml} / \mathrm{min}$, respectively, to change the particle size. When the heating time was over, the tube was cooled down under nitrogen gas flowing at a rate of $5 \mathrm{ml} / \mathrm{min}$. Then after 3 hours has elapsed the catalysts were grinded using a pestle and a mortar

\subsection{Material characterization}

X-ray diffraction (XRD) analyses were carried out on a PANalytical X'Pert Pro diffractometer, fitted with an X'Celerator. The scans covered the range 10-100 degrees and were programmed to a nominal step size of 0.033 degree with a time per step of 10oseconds. The radiation was $\mathrm{Cu} \mathrm{K}_{\alpha}: \lambda=1.5418$ angstroms. The energy dispersive $\mathrm{X}$-ray spectrometer (EDX) analyzer was a Rontec Edwin and the microscope used was a JEOL LV5300. TEM images were obtained using a Tecnai G2 F20X-Twin MAT with $200 \mathrm{kV}$ acceleration voltage.

\begin{tabular}{|c|c|c|c|c|c|}
\hline \multirow[t]{2}{*}{ Electrocatalysts } & \multicolumn{2}{|c|}{$\begin{array}{c}\text { Particle } \\
\text { size (nm) }\end{array}$} & \multirow{2}{*}{$\begin{array}{c}\text { Lattice } \\
\text { constant( }\left(A^{\circ}\right. \\
) \\
\text { XRD }\end{array}$} & \multirow{2}{*}{$\begin{array}{c}\text { Atomic } \\
\text { ratio } \\
\text { determined } \\
\text { by EDX }\end{array}$} & \multirow{2}{*}{$\begin{array}{c}\text { Mass } \\
\text { Activity(A } \\
\text { g-1Pt) }^{-1}\end{array}$} \\
\hline & XRD & TEM & & & \\
\hline $\mathrm{Pt} / \mathrm{C}$ & 2.60 & 3.00 & 0.391 & NA & 716 \\
\hline $\mathrm{Pt} / \mathrm{C}-250$ & 3.10 & $3 \cdot 30$ & 0.394 & NA & 641 \\
\hline $\mathrm{Pt} / \mathrm{C}-350$ & 6.97 & 3.67 & 0.392 & NA & 926 \\
\hline $\mathrm{Pt} / \mathrm{C}-450$ & 8.76 & 3.73 & 0.392 & NA & 672 \\
\hline $\mathrm{Pt}-\mathrm{Co} / \mathrm{C}$ & 3.00 & 3.59 & 0.378 & $\mathrm{Pt}_{53.73} \mathrm{Co}_{46.26}$ & 786 \\
\hline $\mathrm{Pt}-\mathrm{Co} / \mathrm{C}-25 \mathrm{O}$ & 2.55 & 3.89 & 0.386 & $\mathrm{Pt}_{53.76} \mathrm{Co}_{46.23}$ & 980 \\
\hline $\mathrm{Pt}-\mathrm{Co} / \mathrm{C}-35 \mathrm{O}$ & 2.72 & 4.11 & 0.380 & $\mathrm{Pt}_{54.59} \mathrm{Co}_{45.40}$ & 914 \\
\hline $\mathrm{Pt}-\mathrm{Co} / \mathrm{C}-45 \mathrm{O}$ & 3.15 & 4.31 & 0.380 & $\mathrm{Pt}_{54.30} \mathrm{Co}_{45.69}$ & 960 \\
\hline $\mathrm{Pt}-\mathrm{Cu} / \mathrm{C}$ & 3.60 & 4.11 & 0.379 & $\mathrm{Pt}_{49.94} \mathrm{Cu}_{50.00}$ & 869 \\
\hline $\mathrm{Pt}-\mathrm{Cu} / \mathrm{C}-25 \mathrm{O}$ & 3.68 & 4.17 & 0.379 & $\mathrm{Pt}_{53.76} \mathrm{Co}_{46.23}$ & 963 \\
\hline $\mathrm{Pt}-\mathrm{Cu} / \mathrm{C}-350$ & 3.50 & 4.24 & 0.380 & $\mathrm{Pt}_{54.59} \mathrm{Cu}_{45.40}$ & 1151 \\
\hline $\mathrm{Pt}-\mathrm{Cu} / \mathrm{C}-450$ & 5.13 & 4.52 & 0.379 & $\mathrm{Pt}_{47.70} \mathrm{Cu}_{52.29}$ & 1083 \\
\hline $\mathrm{Pt}-\mathrm{Fe} / \mathrm{C}$ & 3.06 & 3.10 & 0.384 & $\mathrm{Pt}_{47.53} \mathrm{Fe}_{52.46}$ & 802 \\
\hline $\mathrm{Pt}-\mathrm{Fe} / \mathrm{C}-250$ & 3.67 & 3.70 & 0.384 & $\mathrm{Pt}_{50.86} \mathrm{Fe}_{49.13}$ & 903 \\
\hline $\mathrm{Pt}-\mathrm{Fe} / \mathrm{C}-350$ & 5.80 & 4.40 & 0.382 & $\mathrm{Pt}_{50.86} \mathrm{Fe}_{49.13}$ & 1131 \\
\hline $\mathrm{Pt}-\mathrm{Fe} / \mathrm{C}-45^{\circ}$ & 9.21 & 9.0 & 0.382 & $\mathrm{Pt}_{48.26} \mathrm{Fe}_{51.73}$ & 1058 \\
\hline $\mathrm{Pt}-\mathrm{Ni} / \mathrm{C}$ & 3.0 & $3 \cdot 36$ & 0.380 & $\mathrm{Pt}_{49.45} \mathrm{Ni}_{50.54}$ & 657 \\
\hline $\mathrm{Pt}-\mathrm{Ni} / \mathrm{C}-250$ & 3.4 & 4.40 & 0.378 & $\mathrm{Pt}_{52.28} \mathrm{Ni}_{47.71}$ & 905 \\
\hline
\end{tabular}




\begin{tabular}{|l|c|c|c|c|c|}
\hline Pt-Ni/C- 350 & 3.61 & 4.80 & 0.376 & $\mathrm{Pt}_{52.55} \mathrm{Ni}_{47.44}$ & 1033 \\
\hline Pt-Ni/C -450 & 4.29 & 5.28 & 0.376 & $\mathrm{Pt}_{52.84} \mathrm{Ni}_{47.15}$ & 950 \\
\hline
\end{tabular}

Table

1.Composi tions,

crystalline sizes, lattice parameters and catalytic activity of various electro-catalysts.

The samples were prepared by suspending a spatula-tip of catalysts powder of interest in ethanol solution and sonicating the solution. A drop of the solution was deposited into the copper grid with carbon.

2.4 Preparation of gas diffusion electrode

$25 \mathrm{mg}$ of catalyst powder, in $75 \mathrm{mg}$ of nafion and 50mg ultrapure water were sonicated for 30 min and 10ml of isopropanol was added and the solution was sonicated for 90 minutes. The solution was then sprayed onto a $4 \mathrm{~cm}^{2}$ area GDL. The resulting composite structure was dried in air at $25^{\circ} \mathrm{C}$ for $1 \mathrm{~h}$, and finally sintered in air at $140^{\circ} \mathrm{C}$ (above the glass transition temperature of Nafion) for $45 \mathrm{~min}$. The $12 \mathrm{~mm}$ puncher was used to cut the gas diffusion electrode which was then assembled in a half cell and the gas diffusion electrode is used as the working electrode. The Pt loadings were $0.25 \mathrm{mg} \mathrm{cm}^{-2}$ in the GDE, respectively. The reduction of oxygen was investigated using the porous GDE (geometric exposed area of $\begin{array}{lllllll}0.785 & \left.\mathrm{~cm}^{2}\right) & \text { in } & 0.5 & \mathrm{M} & \mathrm{H}_{2} \mathrm{SO}_{4} & \text { solution. }\end{array}$

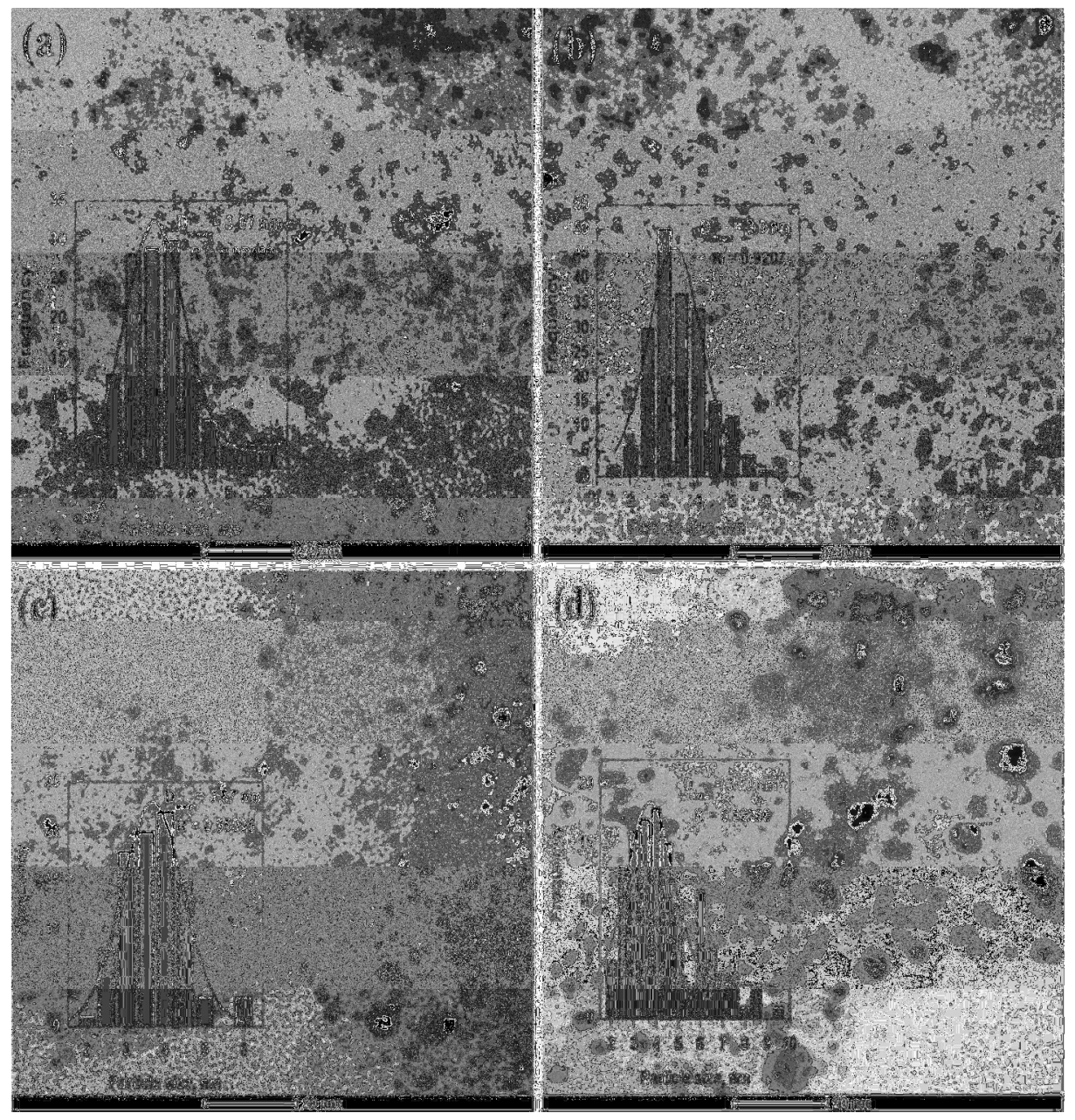

Figure 2. TEM images of Pt/C catalysts (a) unsintered, (b) $250^{\circ} \mathrm{C}$, (c) $350^{\circ} \mathrm{C}$, and (d) $450^{\circ} \mathrm{C}$. Histograms of Ptnano-particle size distributions and mean particle sizes obtained from TEM micrographs 


\subsection{Electrochemical Measurements.}

The electrochemical activity of the catalysts was determined by cyclic voltammetry using the Auto lab PGSTAT 30 (Eco Chemie BV, Netherlands). All experiments were performed at room temperature $\left(\sim 25^{\circ} \mathrm{C}\right)$ in a convectional one-compartment electrochemical glass cell assembled with gas diffusion electrode as the working electrode and $\mathrm{Ag} / \mathrm{AgCl}$ as the reference electrode and platinum mesh as the counter electrode. All electrochemical experiments were performed in $0.5 \mathrm{M}$ sulphuric acid as the electrolyte. Prior to the measurements the working electrode potential was cycled for 20 cycles between -0.2 and $1 \mathrm{~V}$ vs. NHE at $5 \mathrm{OmVs}^{-1}$ scan rate to clean the electrode surface and to obtain stable cyclic voltammograms. The electrolyte solution was purged first before scanning with nitrogen for an hour to purge out the oxygen. For oxygen reduction reaction experiments the electrolyte was bubbled with oxygen for $30 \mathrm{~min}$. and after that the electrode was purged with oxygen while the experiment is running. Then the electrode was screened between 1 and $-0.2 \mathrm{~V}$ at $20 \mathrm{mVs}^{-1}$. Different concentration of methanol was added into the system to monitor which of these electrocatalysts better tolerated the poisoning.

\section{Results and Discussion}

\subsection{X-Ray diffraction study}

Fig. 1(a)shows the XRD results for the heat-treated and untreated Pt/C electrocatalysts. The diffraction pattern of $\mathrm{Pt} / \mathrm{C}$ was included for comparisons. The diffraction peak at $2 \theta$ $\approx 25^{\circ}$ shown for all catalysts are associated to the ( $\left(\begin{array}{lll}0 & 2\end{array}\right)$ plane of the hexagonal structure of the Vulcan XC-72 carbon. The XRD patterns indicate that all electrocatalysts (before and after thermal treatment) present the face centered cubic (FCC) structure of platinum. The broad diffraction peaks suggests the nanocrystalline Pt species on carbon support. The average crystallite sizes of Pt or Pt alloys supported on carbon are calculated from line broadening of the (2 20 ) diffraction peak (Gaussian-Lorentzian peak) according to Scherrer's equation:

$L=0.9 \lambda / \beta_{1 / 2} \cos \theta$

where $\lambda$ is the wavelength of the X-ray (0.15406 nm), $\theta$ is the angle at the position of the peak maximum and $\beta_{1 / 2}$ is the width (in radians) of the diffraction peak at half height and the values are given in Table 1.

Table 1 compares the particle sizes and lattice parameters obtained from the X-ray diffraction data for the $\mathrm{Pt} / \mathrm{C}$ and heat treated catalysts. It is seen that the crystallite size of the Pt particles increased when the electrocatalysts are thermal treated due to the coalescence of the small crystallites. 
Fig.1 (b)-(d) shows XRD spectra of commercial carbon-supported Pt alloy catalysts, with broad peaks at approximately $25^{\circ}$ due to carbon substrates. The Pt alloy catalysts showed three peaks at 39.6, 46.1, and 67.4 ${ }^{\circ}$, which correspond to the diffraction peak of (111), (200), and (220) planes, respectively. The Pt alloy samples after heat treatment are slightly shifted to higher angles, when compared to those of $\mathrm{Pt} / \mathrm{C}$, hence indicating a contraction of the lattice and an insertion of second metal in to the Pt structure, characterizing alloy formation. No peaks corresponding to the oxides were observed. The Pt-Ni, Pt-Fe, and Pt-Co exhibited peak shifts to higher diffraction angles because platinum atoms were partially replaced by smaller metal atoms. The data presented in Table 1 also reveal that Pt-Co binary catalysts exhibit a better resistance to sintering at elevated temperature than the catalysts formed by platinum alone. This effect was also observed for Pt-Cu catalysts ${ }^{16}$, 17.Fig. 1c compares the X-ray diffraction patterns of the $\mathrm{Pt}-\mathrm{Cu} / \mathrm{Ccatalysts}$ after heat treatment at different temperatures. The diffraction peaks of the $\mathrm{Pt}-\mathrm{Cu} / \mathrm{C}$ alloy catalysts shiftto higher angles as compared to that of $\mathrm{Pt} / \mathrm{C}$, indicating a lattice contraction arising from the substitution of the smaller $\mathrm{Cu}$ atoms for the larger Pt atoms. In Fig $\mathbf{1 b} \mathrm{X}$-ray diffraction pattern of $\mathrm{Pt}-\mathrm{Co} / \mathrm{C}\left(250^{\circ} \mathrm{C}\right)$ catalysts exhibit a face centered cubic structure because

Figure 3.TEM images of Pt-Co/C catalysts (a) unsintered, (b) $250^{\circ} \mathrm{C}$, (c) $350^{\circ} \mathrm{C}$, and (d) $450^{\circ} \mathrm{C}$. $\mathrm{Histograms} \mathrm{of}$ Pt-Co nano-particle size distributions and mean particle sizes obtained from TEM micrographs

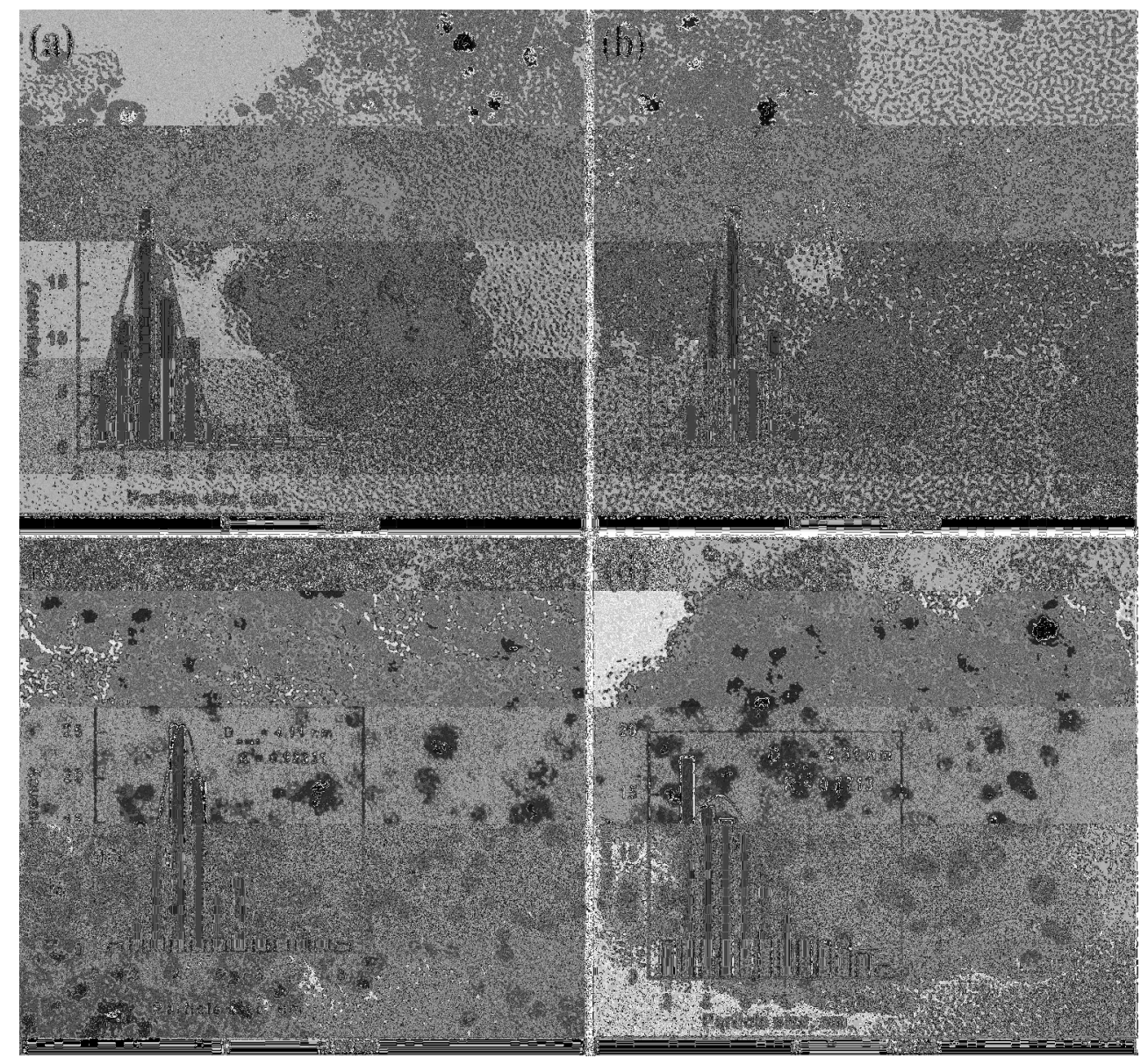

facets (111), (200), (220), (311) and (222) are observed even though (222) is not clearly shown. The peaks are also broad which suggests that the particles are small. The shifts in $2 \theta$ 
correspond to a decrease in lattice constant due to the alloying of Co. The (220) diffraction peak is selected to calculate the particle size and lattice constant which are summarized in Table 1.X-ray diffraction (XRD) analyses indicate that the average particle size is around $2.3 \mathrm{~nm}$, and the lattice parameter is $3.868 \AA$ for $\mathrm{Pt}-\mathrm{Co} / \mathrm{C}-250^{\circ} \mathrm{C}$ (heat-treated under Nitrogen at $\left.250^{\circ} \mathrm{C}\right)$.The particle size of both Pt-Co/C (unsintered) and $\mathrm{Pt}-\mathrm{Co} / \mathrm{C}\left(250^{\circ} \mathrm{C}\right)$ was $3.4 \mathrm{~nm}$ and there was also no change in the particle size of $\mathrm{Pt}-\mathrm{Co} / \mathrm{C}$ sintered at $250^{\circ} \mathrm{C}, 350^{\circ} \mathrm{C}$ and $450^{\circ} \mathrm{C}$ as it remained at $3.3 \mathrm{~nm}$. It is also shown that $\mathrm{Pt}-\mathrm{Co} / \mathrm{C}$ (unsintered) and $\mathrm{Pt}-\mathrm{Co} / \mathrm{C}$ $\left(250^{\circ} \mathrm{C}, 350^{\circ} \mathrm{C}, 450^{\circ} \mathrm{C}\right)$ has the same lattice constant.

The decrease in lattice parameter with heat treatment was observed for Pt-Fe/C and Pt$\mathrm{Ni} / \mathrm{C}$ catalyst. The lattice parameter values for Pt-Fe/C agreed well with the literature [24]. The small lattice constant of the former indicates a higher degree of alloying than the latter. Then it can be concluded that a higher degree of alloying enhances the catalytic activity because $\mathrm{Pt}-\mathrm{Fe} / \mathrm{C}\left(350^{\circ} \mathrm{C}\right)$ is more active than Pt-Fe/C (unsintered) and $\mathrm{Pt}-\mathrm{Fe} / \mathrm{C}\left(250^{\circ} \mathrm{C}\right.$, $450^{\circ} \mathrm{C}$ ) and this will be presented in the electrochemical results in the following section.

\subsection{Elemental composition study}

To confirm the composition of the metal particles, energy dispersive X-ray microanalysis spectra for $20 \% \mathrm{Pt}-\mathrm{Co} / \mathrm{C}, \mathrm{Pt}-\mathrm{Cu} / \mathrm{C}, \mathrm{Pt}-\mathrm{Fe} / \mathrm{C}$ and $\mathrm{Pt}-\mathrm{Ni} / \mathrm{C}$ (unsintered) catalysts and the ones sintered at different temperatures were collected. EDX analysis of the catalysts was performed by reducing the size of the beam and focusing on different areas of the catalysts. Table 1shows EDS results of unsintered and sintered Pt based alloy at different temperatures. The heat treatment does not affect the composition of the catalysts as shown from Table 1 above because the ratio of the catalysts is nearly same even though it was heated at different temperatures. EDX analysis of Pt-Fe/C and Pt-Fe $/ \mathrm{C}-\left(450^{\circ} \mathrm{C}\right)$ confirmed Pt loading of $20 \mathrm{wt} \%$ and a nearly 1:1 Pt to Fe atomic ratio.

\subsection{Transmission Electron Microscopy study}

Figure 2 presents the TEM images of the $20 \%$ commercial $\mathrm{Pt} / \mathrm{C}$ (unsintered)

and sintered catalysts at different temperatures. Uniform size and spherical shaped Pt nanoparticles on the carbon support can be seen in all catalysts. The particle sizes obtained by TEM are given in Table 1. Heat treatment of Pt/C doesn't have much effect on the particles sizes and morphology. The Pt particles generally ranges between 3.0 to $3.7 \mathrm{~nm}$ and were dispersed on carbon support. However, as can be seen in Fig. 2(d) $\mathrm{Pt} / \mathrm{C}\left(450^{\circ} \mathrm{C}\right)$,some Pt agglomerates were observed due to high temperature as compared to other three catalysts. 
TEM analysis of the catalysts shows similar crystallite size for the catalysts comparable tothat found by XRD measurements and a homogeneous distribution of fine metal particles on the support. Transmission electronmicroscopy (TEM) images show very small Pt-Co alloy nanoparticles homogeneously dispersed on the carbon support, with a particle size distribution of 3.5-4.5 $\mathrm{nm}$ for all Pt-Co/C samples, as shown in Fig 3.

Fig 3.show the measurements for the $\mathrm{Pt}-\mathrm{Co} / \mathrm{C}\left(350^{\circ} \mathrm{C}\right)($ Table 1), a mean particle diameter of $4.1 \mathrm{~nm}$ indicating a good particle spatial dispersion without the formation of large particle aggregates was noted. The particle size distribution histograms for all catalysts are reported. Fig 4.shows the heat treatment of $\mathrm{Pt}-\mathrm{Cu} / \mathrm{C}$ catalyst at different temperatures.

Among various alloy catalyst investigated $\mathrm{Pt}-\mathrm{Fe} / \mathrm{C}$ and $\mathrm{Pt}-\mathrm{Ni} / \mathrm{C}$ catalyst shows sharp increase in the particle size with temperature as shown in Fig 5.and Fig 6. Heat treatment has strong influence on the particle size and morphology of

Figure 4.TEM images of Pt-Cu/C catalysts (a) unsintered, (b) $250^{\circ} \mathrm{C}$, (c) $350^{\circ} \mathrm{C}$, and (d) $450^{\circ} \mathrm{C}$. Histograms of Pt-Cunano-particle size distributions and mean particle sizes obtained from TEM micrographs

$\mathrm{Pt}-\mathrm{Fe} / \mathrm{C}$ and $\mathrm{Pt}-\mathrm{Ni} / \mathrm{C}$ catalysts. However, the particle size of the Pt-Fe/C catalysts became large (over $9 \mathrm{~nm}$ )after heat treatment at $450{ }^{\circ} \mathrm{C}$, suggesting there is sintering at high

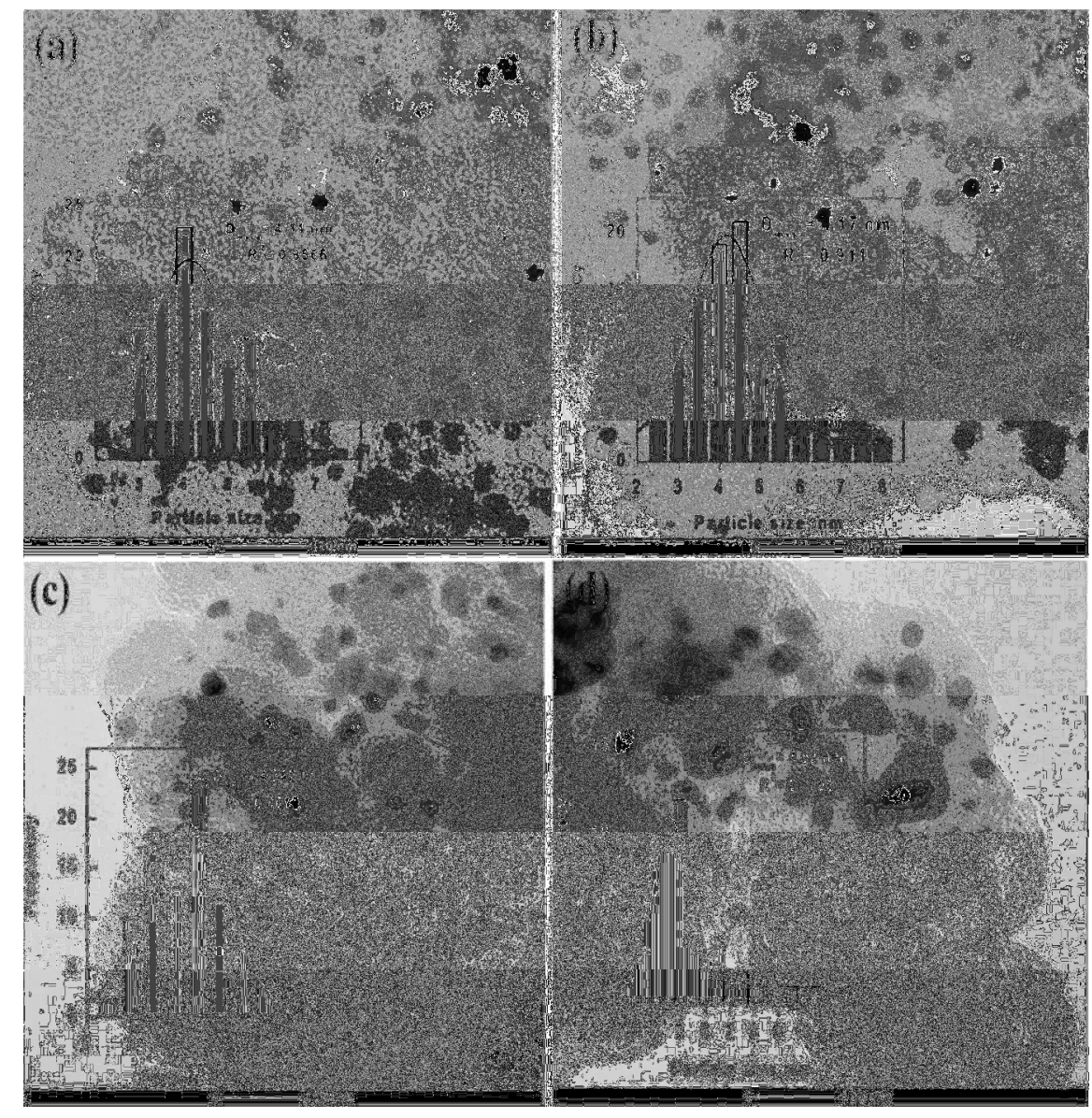

temperature for the Pt-Fe/C catalysts. The particle size of the Pt-Fe/C catalysts is larger than that of Pt-Ni/C catalysts. The sharpening of the $\left(\begin{array}{lll}1 & 1 & 1\end{array}\right)$ diffraction confirms the particle size increase which was witnessed in the TEM examination. In comparison, there was a good agreement with the particle sizes determined using XRD and TEM. 


\subsection{Oxygen reduction reaction on GDEs}

ORR tests are conducted in $0.5 \mathrm{M} \mathrm{H}_{2} \mathrm{SO}_{4}$, which is a weak anion-adsorption acid and can be used to evaluate the mass activity well. Fig. 7 (a) provides an ORR comparison on the $\mathrm{Pt} / \mathrm{C}$ heat treated GDEs under similar experimental conditions. Clearly, among all the GDEs, $\mathrm{Pt} / \mathrm{C}$ without heat treatment displayed the lowest $\mathrm{ORR}$ activity. $\mathrm{Pt} / \mathrm{C}$ heat treated at $350^{\circ} \mathrm{C}$ showed the highest catalytic activity for ORR among the other $\mathrm{Pt} / \mathrm{C}\left(250^{\circ} \mathrm{C}\right.$ and $\left.450^{\circ} \mathrm{C}\right)$ electrodes. The enhanced catalytic activity is attributed to a good combination of factors including the change in Pt-Pt interatomic distance, and the number

Figure 5. TEM images of Pt-Fe/C catalysts (a) unsintered, (b) $250^{\circ} \mathrm{C}$, (c) $350^{\circ} \mathrm{C}$, and (d) $450^{\circ} \mathrm{C}$. Histograms of Pt-Fenano-particle size distributions and mean particle sizes obtained from TEM micrographs

of Pt nearest neighbors ${ }^{17,18}$.

Fig. 7 (b) to $7(\mathbf{e})$ provides ORR comparison on the binary catalysts treated at different temperatures. It is clearly evident that the heat treatment has a positive impact on the catalytic activity for all catalysts. It has to be noted that for all the catalysts, a heat treatment temperature of $350^{\circ} \mathrm{C}$ was found to be the optimum except for $\mathrm{Pt}-\mathrm{Co} / \mathrm{C}$ where the

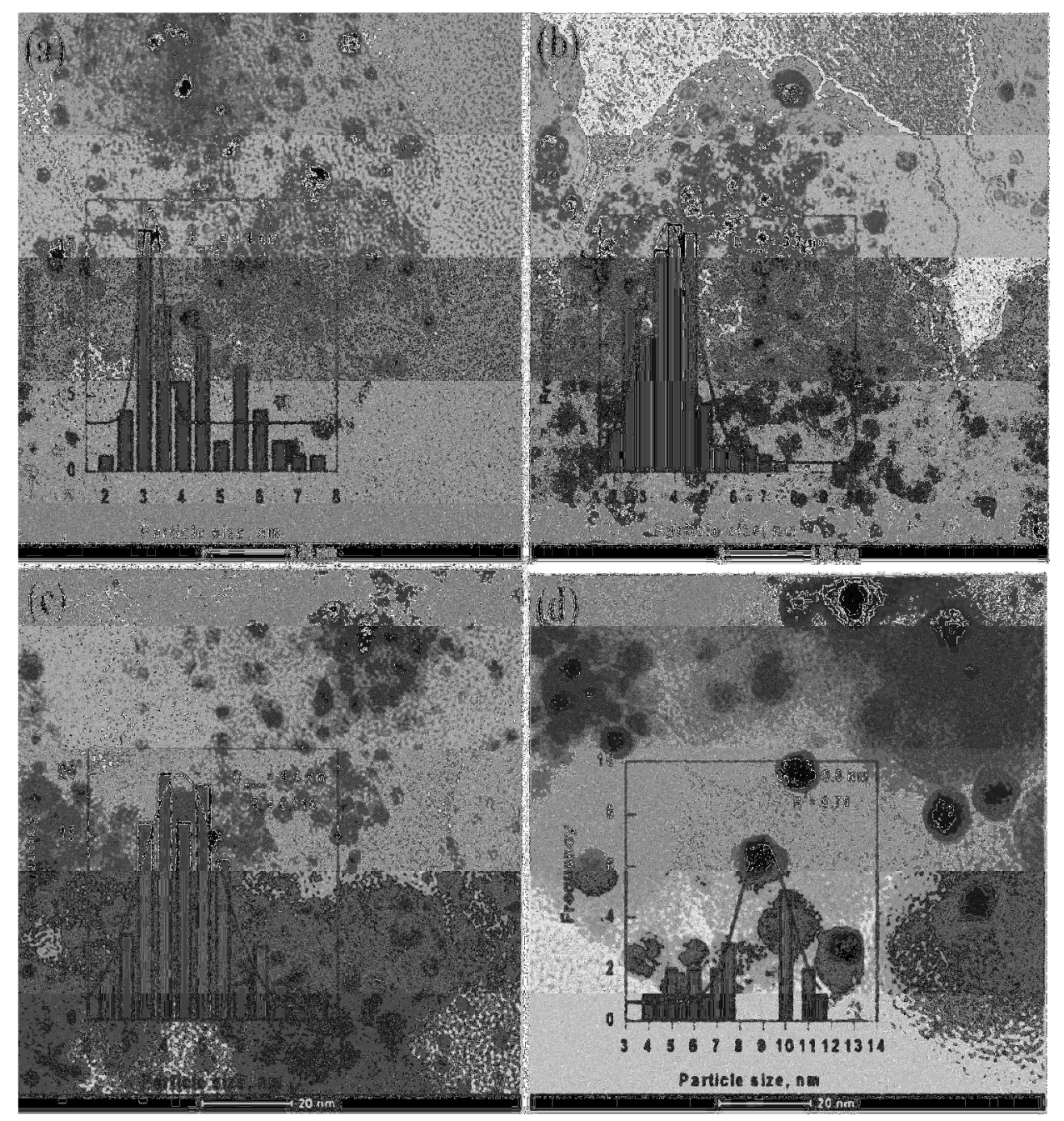

electrochemical activity at $250^{\circ} \mathrm{C}$ was higher than that treated at $350^{\circ} \mathrm{C}$. 

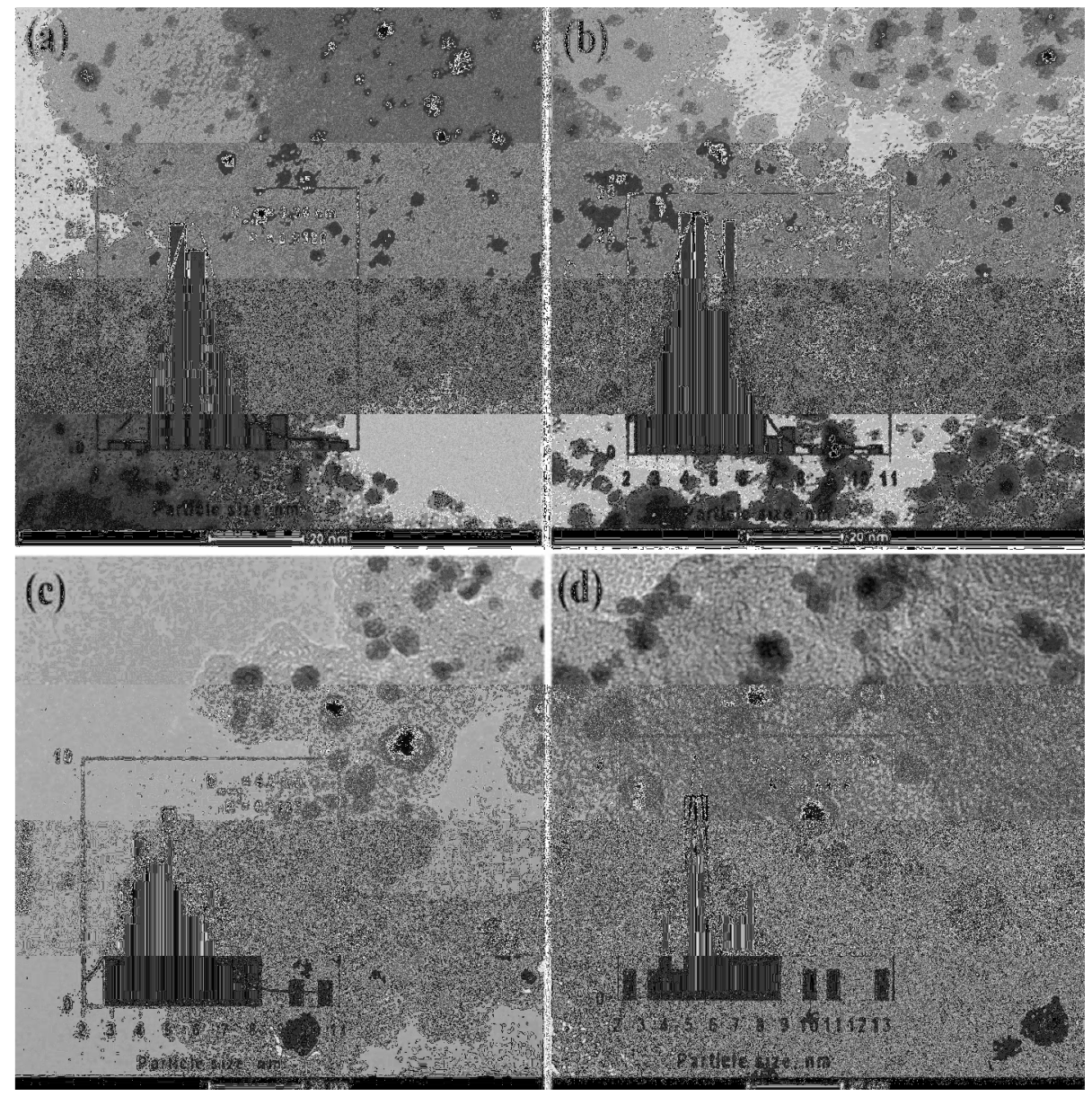

Figure 6. TEM images of Pt-Ni/C catalysts (a) unsintered, (b) $250^{\circ} \mathrm{C}$, (c) $350^{\circ} \mathrm{C}$, and (d) $450^{\circ} \mathrm{C}$. Histograms of Pt-Ninano-particle size distributions and mean particle sizes obtained from TEM micrographs

The activity of ORR follows the order: $\mathrm{Pt}-\mathrm{Cu} / \mathrm{C}\left(35^{\circ}{ }^{\circ} \mathrm{C}\right)>\mathrm{Pt}-\mathrm{Fe} / \mathrm{C}\left(350^{\circ} \mathrm{C}\right)>\mathrm{Pt}-\mathrm{Ni} / \mathrm{C}\left(350^{\circ}\right.$ C) $>\mathrm{Pt}-\mathrm{Co} / \mathrm{C}\left(250^{\circ} \mathrm{C}\right)>\mathrm{Pt} / \mathrm{C}\left(350^{\circ} \mathrm{C}\right)$, showing that $\mathrm{Pt}-\mathrm{Cu} / \mathrm{C}$-type catalysts had a higher ORR activity among the catalysts studied.

Table 1 summarizes the ORR activity amongst other parameters, it has to be noted that there is no significant difference between the morphological properties of the catalysts but a difference in the electrochemical activity is noted. This is attributed to the specific property of the secondary metal introduced to platinum.

In case of $\mathrm{Pt}-\mathrm{Cu} / \mathrm{C}, \mathrm{Pt}-\mathrm{Cu} / \mathrm{C}-350$ shows a higher ORR activity than that of $\mathrm{Pt} / \mathrm{C}$. This may be attributed to the addition of $\mathrm{Cu}$ to $\mathrm{Pt} / \mathrm{C}$ catalyst. The more electropositive based metal $(\mathrm{Cu})$, to which the oxygen species is attached, provides an electrochemical force that favors the four electron oxygen reduction electrochemical pathway, and consequently improves the ORR activity of the catalyst. The addition of $\mathrm{Cu}$ to $\mathrm{Pt} / \mathrm{C}$ catalyst not only reduces the $\mathrm{Pt}$ lattice parameter, but also enhances the catalytic activity. Therefore, the alloying effect is an important factor affecting the catalytic activity towards ORR ${ }^{21}$. 

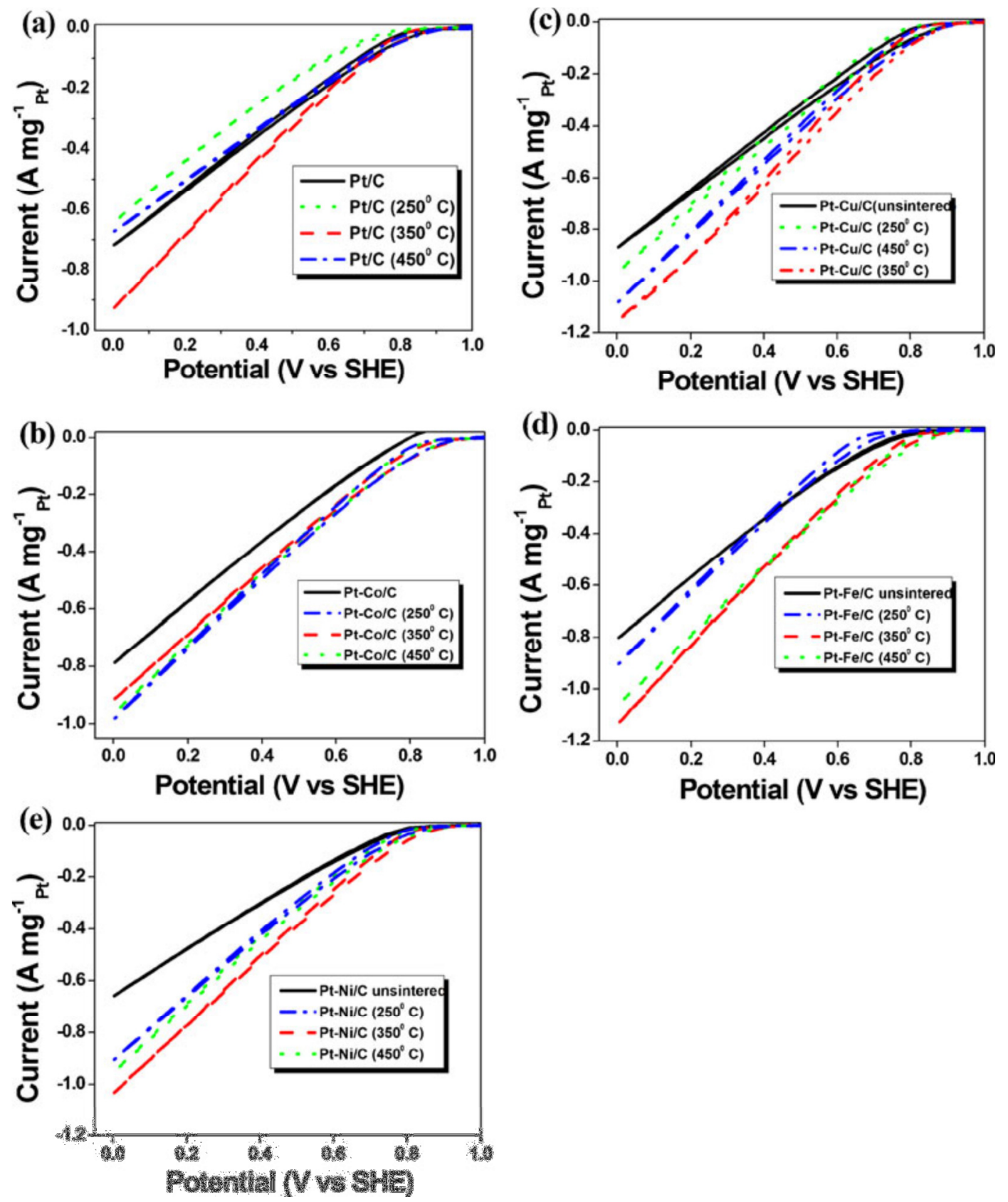

Figure 7.Oxygen reduction curves on (a) Pt/C, (b) Pt-Co/C (c) Pt-Cu/C (d) Pt-Fe/C and (e) Pt-Ni/C catalysts in $\mathrm{O}_{2}$-saturated $0.5 \mathrm{M} \mathrm{H}_{2} \mathrm{SO}_{4}$ in the absence of methanol at $1 \mathrm{mV} / \mathrm{s}$ scan rate.

The reasons for the binary catalysts to be more active towards ORR have been documented extensively in the literature. For example, in the case of Pt-Fe/C it has been reported 22 that the possible factor responsible for the enhancement of ORR is electronic effect. Because $\mathrm{Fe}$ has more vacant $\mathrm{d}$ orbitals, the d-band electrons of Pt will transfer to Fe. So there are more vacant $5 \mathrm{~d}$ orbits of Pt in Pt-Fe alloy compared to Pt alone. This result will render an increase of $2 p$ electron donation from $\mathrm{O}_{2}$ to the surface of $\mathrm{Pt}$, which consequently results in an increased adsorption of $\mathrm{O}_{2}$ on the Pt surface in the alloys. Moreover, since Fe can promote the decomposition of $\mathrm{H}_{2} \mathrm{O}_{2}$, the intermediate of oxygen reduction, to $\mathrm{H}_{2} \mathrm{O}$, favoring the fourelectron oxygen reduction pathway 23 .

\subsection{Oxygen reduction reaction activity on GDEs in the presence of methanol}


The oxygen reduction reaction in the absence and presence of methanol on various electrocatalysts were studied. Fig. 8 shows the cyclic voltammetry scans for the catalysts in methanol containing electrolyte saturated with oxygen. It shows the effect of methanol concentration on the cathodic current of ORR for the sintered catalysts that showed the best ORR activity. It is clearly observed that the cathodic current decreases with increasing methanol concentrations (50 $\mathrm{mM}$ to $1 \mathrm{M}$ ) in all catalysts, indicating the strong influence of methanol oxidation reaction on ORR. An ORR voltammogram for the methanol-free system is also included for comparison.
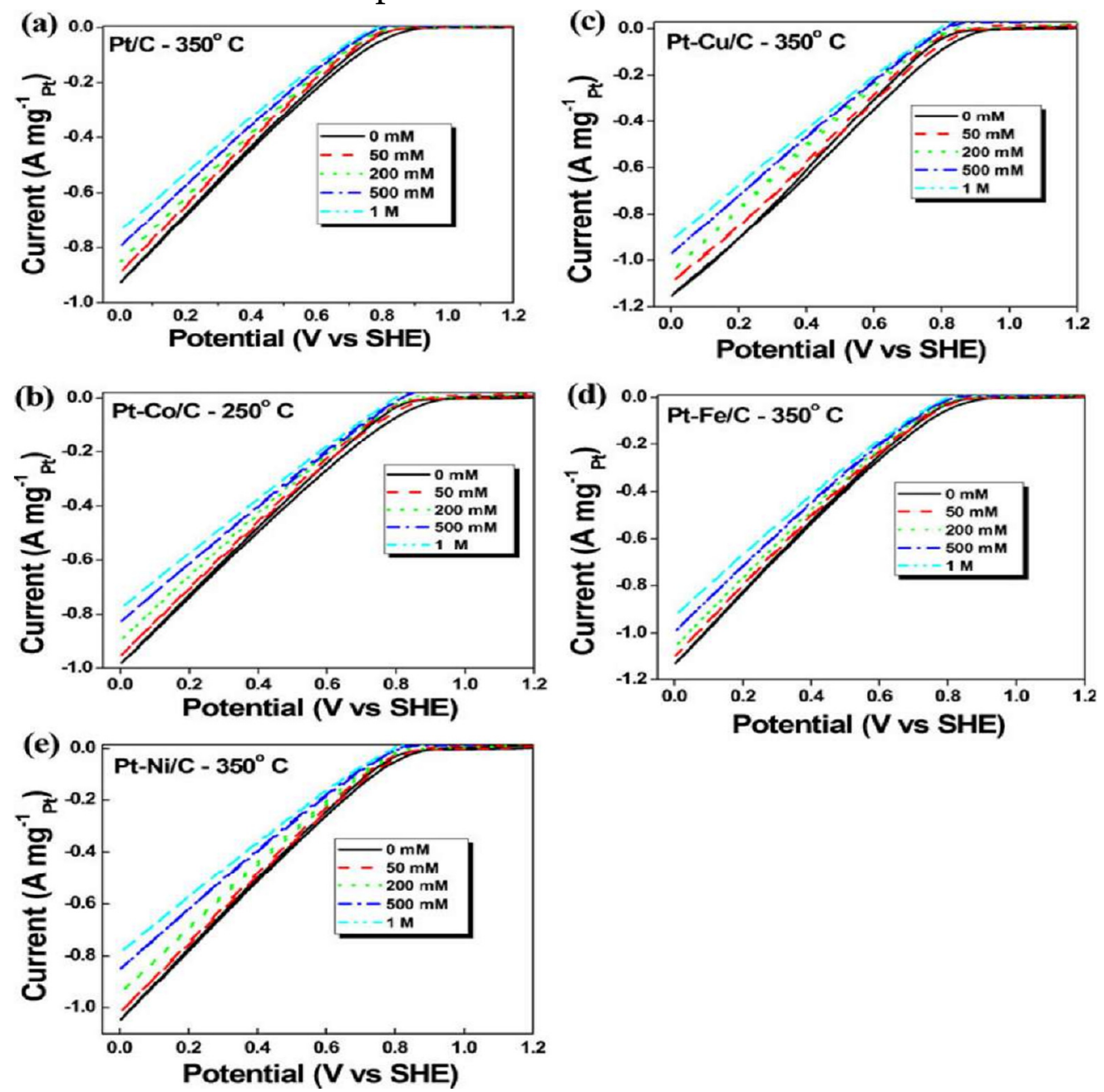

Potential (V vs SHE)

Figure 8. Oxygen reduction curves on (a) Pt/C, (b) Pt-Co/C (c) Pt-Cu/C (d) Pt-Fe/C and (e) Pt-Ni/C catalysts in $\mathrm{O}_{2}$-saturated $0.5 \mathrm{M} \mathrm{H}_{2} \mathrm{SO}_{4}$ at different concentrations of methanol.

As seen in the figure, a significant anodic peak is present during the reduction sweep from 1. $\mathrm{V}$ to $0.6 \mathrm{~V}$ vs. SHE that is not present in the methanol-free solution, in all catalysts is shown except for $\mathrm{Pt} / \mathrm{C}\left(450^{\circ} \mathrm{C}\right)$. It can been seen that irrespective of whether it is $\mathrm{Pt} / \mathrm{C}$ or binary catalysts, all of them shows similar drop in the ORR activity with increasing methanol concentrations. It can be concluded that addition of a secondary metal to Pt does not increase its methanol tolerance during ORR. However, as noted in previous section, the ORR activity improves with the addition of a secondary metal to $\mathrm{Pt} / \mathrm{C}$. Table $\mathbf{2}$ summarizes the ORR activity of best catalysts in $50 \mathrm{mM}$ to $1 \mathrm{M}$ methanol $+0.5 \mathrm{M} \mathrm{H}_{2} \mathrm{SO}_{4}$ solutions. Carbon supported Pt-Co/C alloy electro-catalysts possess enhanced oxygen-reduction activity compared to $\mathrm{Pt} / \mathrm{C}$ in the presence of methanol in sulphuric acid electrolyte. ${ }^{25} \mathrm{Among}$ 
various alloy catalyst investigated $\mathrm{Pt}-\mathrm{Fe} / \mathrm{C}$ found to be an effective methanol-resistant oxygen reduction electrocatalyst. ${ }^{26}$ It can be clearly seen that in the presence of methanol, the ORR activity on all Pt/C catalysts, including binary, decreases in equal proportions with the increase in methanol concentration. The reason is that the binary catalysts equally facilitate the oxidation of methanol as it does with ORR. The results clearly indicate that although the ORR activity of $\mathrm{Pt} / \mathrm{C}$ based catalysts can be improved with introducing secondary metal, its methanol tolerance cannot be improved by these means.

Table2: ORR maximum current density of best electro-catalysts with different methanol concentration

\begin{tabular}{|c|c|c|c|c|c|}
\hline \multirow{2}{*}{ Catalysts } & \multicolumn{5}{|c|}{ Mass Activity(A g-1Pt) } \\
\cline { 2 - 6 } & $\begin{array}{c}\text { omM } \\
\text { Methan } \\
\text { ol }\end{array}$ & $\begin{array}{c}\mathbf{5 0} \mathbf{~ m M} \\
\text { Methanol }\end{array}$ & $\begin{array}{c}\mathbf{2 0 0} \mathbf{~ m M} \\
\text { Methanol }\end{array}$ & $\begin{array}{c}\mathbf{5 0 0} \mathbf{~ m M} \\
\text { Methanol }\end{array}$ & $\begin{array}{c}\text { 1 M } \\
\text { Methan } \\
\text { ol }\end{array}$ \\
\hline $\mathrm{Pt} / \mathrm{C}\left(350^{\circ} \mathrm{C}\right)$ & 926 & 889 & 851 & 795 & 736 \\
\hline $\mathrm{Pt}-\mathrm{Co} / \mathrm{C}\left(250^{\circ} \mathrm{C}\right)$ & 980 & 949 & 892 & 825 & 776 \\
\hline $\mathrm{Pt}-\mathrm{Cu} / \mathrm{C}\left(350^{\circ} \mathrm{C}\right)$ & 1151 & 1093 & 1050 & 969 & 911 \\
\hline $\mathrm{Pt}-\mathrm{Fe} / \mathrm{C}\left(350^{\circ} \mathrm{C}\right)$ & 1131 & 1097 & 1057 & 992 & 926 \\
\hline $\mathrm{Pt}-\mathrm{Ni} / \mathrm{C}\left(350^{\circ} \mathrm{C}\right)$ & 1045 & 1015 & 943 & 848 & 784 \\
\hline
\end{tabular}

\section{Conclusion}

Heat treatment of fuel cell catalysts plays an important role in the improvement of ORR electro-catalytic activity and stability and the optimum heat-treatment temperature with respect to ORR activity is strongly dependent on the individual catalyst. Despite, a number of studies on this topic, there is still no consensus regarding the best binary catalyst for ORR, mainly due to the fact that different methods and conditions were used in those studies. Selected carbon supported platinum electrocatalysts, sourced from one supplier, were treated under controlled conditions at different temperatures and were characterized by XRD, TEM and CV techniques. It was noted that in all the catalysts, the heat treatment had a positive effect on their ORR activity and in most cases a heat treatment temperature of $350^{\circ} \mathrm{C}$ was found to be the optimum. As expected, the particle size of the catalysts was found to increase with increasing treatment temperature. The best ORR activity was noted in the order Pt-Cu $/ \mathrm{C}\left(\mathrm{T}, 350^{\circ} \mathrm{C}\right)>\mathrm{Pt}-\mathrm{Fe} / \mathrm{C}\left(\mathrm{T}, 350^{\circ} \mathrm{C}\right)>\mathrm{Pt}-\mathrm{Ni} / \mathrm{C}\left(\mathrm{T}, 350^{\circ} \mathrm{C}\right)>\mathrm{Pt}-\mathrm{Co} / \mathrm{C}\left(\mathrm{T}, 250^{\circ} \mathrm{C}\right)>$ $\mathrm{Pt} / \mathrm{C}\left(\mathrm{T}, 35 \mathrm{O}^{\circ} \mathrm{C}\right)$.

The methanol tolerance of the catalysts was studied in oxygen saturated electrolyte with various concentrations of methanol. It was found that the presence of methanol reduced the ORR activity of all the catalysts and was proportional to the concentration of methanol. Heat treatment of $\mathrm{Pt} / \mathrm{C}$ or the addition of secondary metals did not have any effect on the 
methanol tolerance of the catalysts, which indicate that the sintering or the presence of secondary metal did not have any effect on neither the absorbance nor the catalytic activity towards methanol in oxygen saturated solutions.

It can be concluded that the ORR activity of $\mathrm{Pt} / \mathrm{C}$ can be improved through heat-treatment and introducing secondary metals but not the methanol tolerance of these ORR catalysts. 


\section{References}

1. T. Maiyalagan, T.O. Alaje, K. Scott, J. Phys. Chem. C, 116, 2630 (2012)

2. T. Maiyalagan, B. Viswanathan, U.V. Varadaraju, Electrochem. Commun. 7, 905 (2005)

3. T. Maiyalagan, P. Sivakumar, Mater Sci Forum 657, 143 (2010)

4. H.A. Gasteiger, N. Markovic, P.N. Ross, E.J. Cairns, J Phys Chem.97, 12020 (1993)

5. S. Gilman, D. Chu. Handbook of fuel cells-fundamentals, technology and applications 2, 653 (2003)

6. V. Baglio, A.S. Aricó, A. Stassi, C. D’Urso, A. Di Blasi, A.M.Castro Luna, V. Antonucci, J. Power Sources 159, 900 (2006)

7. H. Yang, N. Alonso-Vante, C. Lamy, D.L. Akins, J Electrochem.Soc 152, A704 (2005)

8. X. Zhao, M. Yin, L. Ma, L. Liang, C. Liu, J. Liao, T. Lu, W. Xing,Energy Environ. Sci., 4, 2736 (2011)

9. V. Baglio, A. Stassi, A. Di Blasi, C. D’Urso, V. Antonucci, A.S.

Aricò, Electrochim Acta 53, 361 (2005)

10. V. Baglio, A. Di Blasi, C. D’Urso, V. Antonucci, A.S. Aricò, R.Ornelas, D. Morales-Acosta, J. Ledesma-Garcia, L.A. Godinez, L.

Morales-Alvarez, L.G. Arriaga, J Electrochem Soc 155, B829 (2008)

11. L.G.R.A. Santos, C.H.F. Oliveira, I.R. Moraes, E.A. Ticianelli, J. Electroanal Chem 596, 141 (2006)

12. H. Yang, C. Coutanceau, J.-M. Le`ıger, N. Alonso-Vante, C. Lamy, J Electroanal Chem 576, 305 (2005)

13. S. Mukerjee, S. Srinivasan, M.P. Soriaga, J. McBreen, J Electrochem.Soc 142, 1409 (1995)

14. Y. Bing, H. Liu, L. Zhang, D. Ghosh, J. Zhang, Chem Soc Rev 39,2184 (2010)

15. C.W.B. Bezerra, L. Zhang, H. Liu, K. Lee, A.L.B. Marques, E.P.Marques, H. Wang, J. Zhang, J Power Sources 173, 891 (2007)

16. L. Xiong, A.M. Kannan, A. Manthiram, Electrochem Commun 4,898 (2002)

17. E. Antolini, J. Mater. Sci. 38, 2995 (2003)

18. J.K. Norskov, J. Rossmeisl, A. Logadottir, L. Lindqvist, J.R.Kitchin, T. Bligaard, H. Jónsson, J. Phys. Chem. B 108, 17886

(2004)

19. H.A.Gasteiger, S.S. Kocha, B. Sompalli, F.T. Wagner, Appl. Catal. B. 46, 9 (2005)

20. S. Koh, N. Hahn, C. Yu, P .Strasser, P. J. Electrochem. Soc. 155,B1281 (2008)

21. C.J. Tseng, S.T. Lo, S.C. Lo, P.P. Chu, Mater Chem Phys 100, 385 (2006)

22. K.L. Hsueh, E.R. Gonzalez, S. Srinivasan, D.T. Chin, J Electrochem.Soc 131, 823 (1984)

23. W.Z. Li, W.J. Zhou, H.Q. Li, Z.H. Zhou, B. Zhou, G.Q. Sun, Q.Xin, Electrochim Acta 49, 1045 (2004)

24. L. Xiong, A. Manthiram, J Electrochem Soc 152, A697 (2005)

25. J.R.C. Salgado, E. Antolini, E.R. Gonzalez, Appl Catal B: Environ 57, 283 (2005)

26. M. Neergat, A.K. Shukla, K.S. Gandhi, J Appl Electrochem 31,373 (2001) 


\section{List of Figure captions}

Fig. 1.XRD pattern of (a) Pt/C (b) Pt-Co/C (c) Pt-Cu/C (d) Pt-Fe/C and (e) Pt- Ni/C catalyst

Fig. 2. TEM images of $\mathrm{Pt} / \mathrm{C}$ catalysts (a) unsintered, (b) $250^{\circ} \mathrm{C}$, (c) $350^{\circ} \mathrm{C}$, and (d) $450^{\circ} \mathrm{C}$. Histograms of Ptnano-particle size distributions and mean particle sizes obtained from TEM micrographs

Fig. 3.TEM images of Pt-Co/C catalysts (a) unsintered, (b) $250^{\circ} \mathrm{C}$, (c) $350^{\circ} \mathrm{C}$, and (d) $450^{\circ} \mathrm{C}$. Histograms of Pt-Conano-particle size distributions and mean particle sizes obtained from TEM micrographs

Fig. 4.TEM images of $\mathrm{Pt}-\mathrm{Cu} / \mathrm{C}$ catalysts (a) unsintered, (b) $250^{\circ} \mathrm{C}$, (c) $350^{\circ} \mathrm{C}$, and (d) $450^{\circ} \mathrm{C}$. Histograms of Pt-Cunano-particle size distributions and mean particle sizes obtained from TEM micrographs

Fig. 5. TEM images of $\mathrm{Pt}-\mathrm{Fe} / \mathrm{C}$ catalysts (a) unsintered, (b) $250^{\circ} \mathrm{C}$, (c) $350^{\circ} \mathrm{C}$, (d) $450^{\circ} \mathrm{C}$. Histograms of Pt-Fenano-particle size distributions and mean particle sizes obtained from TEM micrographs

Fig. 6. TEM images of Pt-Ni/C catalysts (a) unsintered, (b) $250^{\circ} \mathrm{C}$, (c) $350^{\circ} \mathrm{C}$, (d) $450^{\circ} \mathrm{C}$. Histograms of Pt-Ninano-particle size distributions and mean particle sizes obtained from TEM micrographs

Fig. 7.Oxygen reduction curves on (a) Pt/C, (b) Pt-Co/C (c) Pt-Cu/C (d) Pt-Fe/C and (e) Pt$\mathrm{Ni} / \mathrm{C}$ catalysts in $\mathrm{O}_{2}$-saturated $0.5 \mathrm{M} \mathrm{H}_{2} \mathrm{SO}_{4}$ in the absence of methanol at $1 \mathrm{mV} / \mathrm{s}$ scan rate

Fig. 8. Oxygen reduction curves on (a) $\mathrm{Pt} / \mathrm{C}$, (b) $\mathrm{Pt}-\mathrm{Co} / \mathrm{C}$ (c) $\mathrm{Pt}-\mathrm{Cu} / \mathrm{C}$ (d) $\mathrm{Pt}-\mathrm{Fe} / \mathrm{C}$ and (e) $\mathrm{Pt}-\mathrm{Ni} / \mathrm{C}$ catalysts in $\mathrm{O}_{2}$-saturated $0.5 \mathrm{M} \mathrm{H}_{2} \mathrm{SO}_{4}$ at different concentrations of methanol. 